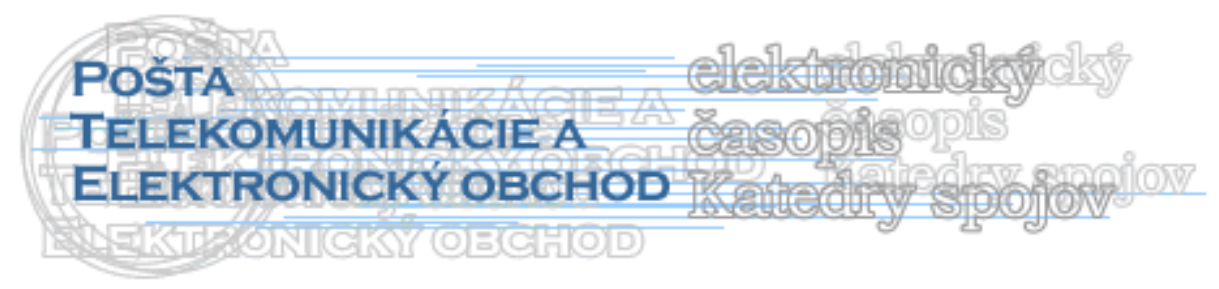

\title{
ELEKTROMOBILITA A PERSPEKTÍVY JEJ ROZVOJA
}

\section{Lucia Madleňáková1, Radovan Madleňák ${ }^{2}$}

\begin{abstract}
Recent researches and innovations in the field of electromobility indicate positive trends in market development. Almost every car producer currently has an electric vehicle model on offer. Some producers are rapidly expanding their range of models, because the demand for electric cars increases. T\&E's (Transport and Environment) also predicts the imminent end of sales of new cars with internal combustion engines. This was also confirmed by some producers, especially in the European market (Volkswagen, Audi, Volvo, ..) The reason is also strict emission regulation. According to Bloomberg New Energy Finance, a significant determinant of the development of electromobility is also the price of batteries, the state subsidies, the planned restrictions on the use of internal combustion engines, especially in the countries of Western Europe, and the strong environmental feelings of the country and its population (e.g., Norway, Netherlands...). From an economic point of view, it is to reduce dependence on fossil fuels. Insufficient infrastructure and the real range of the vehicle appear to be a negative aspect of the development of electromobility in some countries. The paper aims to identify the impact development of economy on the electromobility based on quantitative analysis. The research question seeks to find answers about the development of electric car markets. The basic model works with quarterly data on gross domestic product per capita and with number of registered BEVs in the surveyed countries. The regression models use to data from relevant statistical databases from the OECD, the European Alternative Fuels Observatory, The Global Electric Vehicle Policy Database, and the Nation statistics dataset.
\end{abstract}

Keywords: electric vehicle; electric vehicles registration; gross domestic product per capita; subsidies.

\section{1. Úvod do problematiky}

Elektromobilita definuje koncept cestnej dopravy ako systém, ktorého zložky tvoria vozidlá vybavené elektrickou trakciou, infraštruktúra pre elektromobily, potrebné informačné technológie a legislatíva. Prechod na elektromobilitu zvýši závislost' spoločnosti na elektrickej energii. Kl'účovou úlohou je zaistenie dostupnosti surovín pre nízko uhlíkovú výrobu elektrickej energie, bezpečnost', stabilitu a efektívne riadenie elektrickej prenosovej sústavy, čo bude dôležité v prípade súbežného nabíjania väčšieho počtu elektrických vozidiel v domácnostiach v husto osídlených oblastiach. Mnohí autori upozorňujú aj nato, že práve doprava je jedným z hlavných sektorov, ktoré sú zodpovedné za emisie EÚ. [3, 4, 7, 8, 11, 14, 22] Jej vplyv na životné prostredie či ekonomiku a udržatel'nost' krajiny možno nájst' v prácach iných autorov $[2,4,9-13,22,23,25,26]$.

\footnotetext{
${ }^{1}$ doc. Ing. Lucia Madleňáková, PhD., Žilinská univerzita v Žiline, FPEDAS, Katedra spojov, Univerzitná 8215/1, 01026 Žilina, e-mail: lucia.madlenakova@fpedas.uniza.sk

${ }^{2}$ prof. Ing. Radovan Madleňák, PhD., Žilinská univerzita v Žiline, FPEDAS, Katedra spojov, Univerzitná 8215/1, 01026 Žilina, e-mail: radovan.madlenak@fpedas.uniza.sk
} 
Elektromobilu je potrebné chápat' z pohl'adu globálneho a národného:

Aspekty rozvoja elektromobility vo svete $[2,3,5,6,23]$

Tempo rozvoja a podielu hybridných a elektrických vozidiel $\mathrm{v}$ jednotlivých častiach sveta závisí najmä od:

- aktivity a orientácie národných vlád na iniciáciu trhu s elektromobilmi a reguláciu na úrovni EÚ,

- vývoja svetových cien ropy a cien pohonných hmôt,

- cenovej dostupnosti a nákladov na prevádzku počas celého životného cyklu elektrického vozidla,

- postupného rozširovania infraštruktúry a vel'kokapacitnej produkcie elektrických vozidiel,

- tempa technického pokroku a inovácií batérií vo väzbe na cenu a energetickú hustotu. Aspekty rozvoja elektromobility na Slovensku $[6,22]$

- silná pozícia automobilového priemyslu a dodávatel'ských spoločností,

- znižovanie závislosti na dovoze fosílnych palív,

- ochrana životného prostredia,

- podpora inovácií, vedy a výskumu,

- priame a nepriame podporné mechanizmy na stimuláciu rozvoja elektromobility:

o podpora rozvoja infraštruktúry,

- podpora vo forme úl'av $\mathrm{z}$ daní a poplatkov,

○ dotácie súvisiace s obstaraním vozidla.

\section{Analýza súčasného stavu}

\subsection{Trendy rozvoja elektromobility}

Celosvetový trhový podiel elektromobilov dosiahol v roku 2019 rekordných 2,6 \% celosvetového predaja áut. Expanzia elektromobilov sa prejavila na všetkých hlavných trhoch okrem Japonska, Kórey a Spojených štátov amerických. Celosvetovo sa v roku 2020 počet osobných automobilov nad'alej zvyšoval rýchlym tempom a dosiahol úroveň 10,2 mil. kusov, čo predstavovalo $40 \%$ nárast oproti roku 2019 . Ćína so 4,5 mil. elektrických áut mala najväčšiu flotilu, hoci v roku 2020 mala Európa najväčší ročný nárast 3,2 mil. Európa s 1,7 mil. elektromobilov $\mathrm{v}$ roku 2020 tvorila $25 \%$ celosvetových zásob a 1,2 mil. kusov elektromobilov v USA predstavovalo $20 \%$. Nórsko bolo globálnym lídrom na základe podielov elektromobilov s $13 \%$ podielom celkových zásob v roku 2020. Batériové elektrické vozidlá (BEV) tvorili v roku 2020 dve tretiny registrácií nových elektromobilov. [9,11,16-21]

Postupne sa rozširuje aj ponuka modelov elektromobilov. V roku 2019 bolo celosvetovo dostupných približne 250 modelov (v roku 2014 to bolo len okolo 70 modelov). Očakáva sa, že do roku 2025 príde na trh viac ako 200 nových modelov. Rovnako tak technologické vylepšenia zvyšujú atraktivitu elektromobilov pre spotrebitel'ov. Čas nabíjania sa výrazne skracuje a zároveň sa znižujú náklady na batérie. [10,12,16-21]

Infraštruktúra pre nabíjanie elektrických vozidiel je dôležitým prvkom dostupnosti pre elektromobilitu. Do konca roku 2019 bolo na celom svete nainštalovaných 7,3 mil. nabíjačiek pre elektrické vozidlá, z čoho 6,5 mil. nabíjačiek tvorili pomalé alebo normálne nabíjačky pre súkromné l'ahké úžitkové vozidlá. Ponuka a dostupnost' nabíjačiek vzrástla o 40 \% z 5,2 mil. v roku 2018. [10,12,16-21] Avšak aj v súčasnosti vidíme, že nabíjacia infraštruktúra nie je dostatočná. Podl'a Európskeho združenia výrobcov automobilov (ACEA) je v Európe stále nedostatok nabíjacích staníc, pričom 10 krajín EÚ nemá v priemere ani jeden terminál na 100 $\mathrm{km}$. Z Európskych krajín je infraštruktúra pre elektromobily najviac rozvinutá v Holandsku, čo predstavuje 47,5 nabíjacích staníc na $100 \mathrm{~km}$, nasleduje Luxembursko (34,5 nabíjacích 
staníc/100 km), Nemecko (19,4 nabíjacích staníc/100 km), Portugalsko (14,9 nabíjacích staníc na $100 \mathrm{~km})$ a Rakúsko $(6,1$ nabíjacích staníc/100 km). Najmenej nabíjacích staníc na $100 \mathrm{~km}$ je v Litve, Pol'sku, Cypruse, Lotyšsku a Rumunsku. Na Slovensku je to v priemere 2 nabíjacie stanice na $100 \mathrm{~km}$. [1]

Prognózy vývoja elektromobility vo svete

IEA (Medzinárodná energetická agentúra) vo svojich scenároch globálneho výhl'adu pre elektrické vozidlá (EV) predpovedá 130 - 250 mil. EV v roku 2030, pričom podiel EV vo vozovom parku by mal vzrást' z 0,2 \% v 2016 na viac ako $5 \%$ v roku 2030. [4] Táto prognóza zahíňa nielen osobné a l'ahké úžitkové vozidlá, ale aj autobusy a nákladné vozidlá. Okrem IEA zdiel'ajú podobný názor o celosvetovom vývoji EV aj iné spoločnosti ako napríklad:

- Medzinárodná agentúra pre obnovitel'né zdroje $\mathrm{v}$ analýze o smart nabíjaní EV predpokladá 150 mil. osobných EV v roku 2030 a viac ako 1 mild. EV v 2050,

- podl'a KBC budú po svete jazdit' 2 mild. EV do roku 2040,

- podl'a Morgan Stanley bude v roku 2030 až 320 mil. EV a v 2050 1,6 mild., čo bude vtedy tvorit' polovicu celosvetového vozového parku,

- Bloomberg New Energy Finance (BNEF) predpovedá celosvetovo 28 - 30 mil. novopredaných osobných EV v roku 2030,

- Boston Consulting Group predpokladá, že v roku 2030 bude 46\% novopredaných osobných vozidiel vo svete elektrických,

- Deloitte predpokladá, že sa v roku 2030 predá celosvetovo 21 mil. osobných elektrických vozidiel ročne,

- podl'a JP Morgan budú EV v roku 2030 tvorit' 20\% globálneho vozového parku.

BNEF publikoval v roku 2019 prognózu, podl'a ktorej elektrické autobusy budú v roku 2040 tvorit' celosvetovo $68 \%$ všetkých autobusov a l'ahké úžitkové elektrické vozidlá $38 \%$ vozidiel vo svojej kategórii. V nákladnej a kamiónovej doprave by sa mali vo väčšej miere okrem elektrického pohonu začat' využívat' vozidlá s pohonom na alternatívne palivá ako zemný plyn alebo vodík, ktoré sú vhodnejšie pre t’ažkú nákladnú dopravu.

Prognóza rozvoja elektromobility $v$ SR

Rozvoj elektromobility na Slovensku, ale aj vo svete, sa v súčasnosti nachádza medzi fázou zavádzania a fázou rastu. Analýza historických trendov zavádzania technologických inovácií poukazuje na strmší nárast dopytu po získaní 2,5 - $5 \%$ podielu na trhu. Toto rozpätie by pri súčasnom počte 2,33 milióna osobných vozidiel v SR predstavovalo 58-tisíc až 116tisíc EV. Scenár založený na prognóze z Akčného plánu rozvoja elektromobility MH SR predpokladal 10-tisíc EV vo vozovom parku SR v roku 2020 (čo predstavuje 0,4 \% vozidiel kategórie M1 v súčasnom vozovom parku), 20-tisíc vozidiel v roku 2025 (0,9\%) a 35-tisíc EV v roku 2030 (1,5\%). Analýzy za roky 2020 však nepotvrdili tento vývoj v SR. Z údajov Zväzu automobilového priemyslu SR vyplýva, že podiel elektromobilov na celkovom predaji je stále pomerne zanedbatel'ný. Za prvých šest' mesiacov roku 2021 sa na Slovensku predalo len 432 elektromobilov. Najviac z nich bolo značky VW, nasledovala Škoda a Kia. V roku 2020 sa na Slovensku predalo 918 elektromobilov čo predstavuje 1,2 \% podiel na celkovom predaji automobilov. Počet registrovaných automobilov v roku 2015 predstavoval 224 elektromobilov. V roku 2019 prvýkrát presiahol hranicu tisíc registrovaných vozidiel (1194 registrácií) a v roku 2020 to bolo 1946 registrovaných elektromobilov. [22,27]

\subsection{Finančné faktory elektromobility a jej podpory}

Medzi najvýznamnejšie finančné faktory patrí cena vozidla, cena batérie, náklady na prevádzku, údržbu a opravy vozidla, či cena paliva - elektriny, ropy. Spotrebitel'a zaujíma návratnost' investície do EV a zväčša je porovnávaná s kúpou automobilu na pohon $\mathrm{z}$ 
fosílnych palív. Finančné náklady nákupu a prevádzky elektromobilov a áut na konvenčný pohon porovnal aj Inštitút pre environmentálnu politiku. [22].

Výskumy ukazujú, že vyššia obstarávacia cena EV môže odradit' čast' spotrebitel'ov. V krajinách EÚ s hrubým domácim produktom (HDP) na obyvatel'a pod 29000 eur/obyv. mali v roku $2018 \mathrm{EV}$ menší ako $1 \%$ podiel na registráciách nových vozidiel. [1, 12] Je to takmer polovica krajín EÚ, najmä členské štáty strednej a východnej Európy, ale aj Španielsko, Taliansko a Grécko.

Významný finančný aspekt predstavuje podpora štátu v podobe dotácií, úl'av na poplatkoch a daniach. Tento trend sa následne prejavuje aj v počte registrovaných vozidiel, kde popredné priečky v Európe si udržiava Nórsko. Nemecko, Francúzsko či Holandsko. Ako príklad uvádzame Nórsko, ktoré poskytuje štedré dotácie a úl'avy prevádzkovatel'om elektromobilov. EV sú oslobodené od DPH, neplatia cestnú daň, neplatia mýtne poplatky, majú $50 \%$ zl'avu z trajektov, môžu využívat' pruhy pre verejnú dopravu, získavajú oslobodenie od poplatkov za parkovanie, oslobodený vstup do centra od registračnej dane a pod. [12] Tieto benefity súvisia s environmentálnou politikou krajiny a s ciel'om dosiahnut' do roku 2025 nulové emisie na všetky predané vozidlá. [12, 21, 22] Naopak krajiny strednej a východnej Európy systém podpory predaja EV s dotáciami vybudovaný nemajú. Ide skôr o ojedinelé a jednorazové dotácie. $\mathrm{V}$ budúcnosti podl'a vládnych dokumentov a memoránd môžu aj motoristi v SR a ČR počítat' $s$ dotáciami, tie však budú naplno uplatňované pravdepodobne až po roku 2025. [12, 22, 24]

\section{Ciel' a metodika}

V súvislosti s hl'adaním globálnych riešení klimatickej krízy je $\mathrm{v}$ súčasnej dobe problematika elektromobility jednou $\mathrm{z}$ najdiskutovanejších tém. Vel'ký vplyv na rozvoj elektromobility má postoj konkrétnej krajiny v rámci zvolenej politiky. Ciel’om príspevku je skúmanie vplyvu úrovne hrubého domáceho produktu (HDP) na rozšírenie elektrických vozidiel v podmienkach vybraných krajín. Sú to dve skupiny európskych krajín s rozdielnym prístupom a vývojom elektromobility: krajiny s vel'kým podielom registrovaných elektrických vozidiel (Nórsko, Švédsko, Holandsko), krajiny, kde sa tieto trendy ešte len začínajú presadzovat' (SR, ČR, Island). HDP je základným parametrom, v ktorom sa odráža kúpyschopnost' obyvatel'stva. Tá je často primárnym aspektom ovplyvňujúcim obstarávanie vozidla v zákazníckom segmente občan. Vývoj trhov BEV je pozorovaný medzi obdobiami Q1 2011 - Q4 2020. Skúmaniu sú podrobné dáta získané z databáz OECD [15] založené na štvrt'ročnej periodicite. Vel'kost' trhu je vyjadrená počtom novo registrovaných elektromobilov v kategórii batériové vozidlá (BEV) v príslušnej krajine. Využité boli tiež štatistické údaje z portálu European Alternative Fueals Observatory a svetovej databázy predajov elektrických vozidiel (EV Volumes) [16,20]. Pre skúmanie vplyvu výšky HDP na obyvatel'a a novo registrovaných vozidiel bol využitý SW štatistický nástroj SPSS. Dáta boli podrobené kontrole normálneho rozdelenia. Pre interpretáciu záverov a stanovenie regresnej rovnice bolo nutné skúmat' rôzne štatistické charakteristiky: sila vzt'ahu medzi skúmanými premennými je zist'ovaná prostredníctvom Pearsonovho korelačného koeficientu (R), a tiež koeficientu determinácie (R Square), ktorý vysvetl'uje kol'ko percent variability závislej premennej Y (novo registrované BEV) ovplyvňuje nezávislá premenná X (HDP).

\section{Výsledky a diskusia}

Existencia závislosti medzi počtom registrovaných BEV a HDP, ktorý je jedným z aspektov determinujúcich kúpyschopnost' obyvatel'stva bolo realizované na základe lineárnej regresnej analýzy. 
Hypotézy výskumu:

Ho: Hodnota HDP na obyvatel'a nemá štatisticky významný vplyv meraný lineárnou regresiou na počet novo registrovaných BEV.

$\mathrm{H}_{1}$ : Hodnota HDP na obyvatel'a má štatisticky významný vplyv meraný lineárnou regresiou na počet novo registrovaných $\mathrm{BEV}$.

V nasledujúcom texte sú prezentované výsledky hodnoteného vývoja trhov v skúmaných krajinách (podl'a HDP na obyvatel'a) vo väzbe na registrovaný počet BEV. Pre nedostatok priestoru uvádzame grafické znázornenie vývoja trhov len pre SR a Holandsko. Pričom rovnakým spôsobom boli pri skúmaní znázornené aj trhy d'alších krajín. Na os $\mathrm{X}$ nanesené absolútne hodnoty HDP na obyvatel'a $v$ US dolároch $\mathrm{v}$ skúmaných kvartáloch a na os Y počty kvartálnych registrácií BEV.

Prvú skupinu skúmaných krajín tvorí SR, ČR a Island, ktoré sú považované za krajiny, kde sa trendy elektromobility ešte len začínajú presadzovat'. Zároveň je Island podl'a hodnotiacich správ považovaný za krajinu, kde sa v poslednom období výrazným spôsobom začínajú využívat' alternatívne palivá.

Slovenskýtrh



Obrázok 1 Trend vývoja elektromobility na slovenskom trhu

Obrázok 1 ukazuje, že so zvyšujúcim sa HDP rastú aj počty registrovaných elektromobilov, to znamená ak sa zvýši HDP o 1000 dolárov, zvýši sa počet registrovaných BEV o 19 ks. Medzi skúmanými veličinami existuje závislost' a model vyjadruje, že 31\% variability závislej premennej ovplyvňuje nezávislá premenná. Ako vidiet', počet vozidiel v porovnaní s inými krajinami sa pri raste HDP zvyšuje len nepatrne. Môžeme sa domnievat', že jedným z dôvodov, na ktoré sme už upozorňovali, je aj nevýrazná dotačná podpora zo strany štátu. Na konci roku 2019 vyčlenila vláda SR 6 mil. eur, pričom na nákup nového vozidla s čisto elektrickým pohonom bolo možné získat' príspevok 8000 eur a v prípade plugin hybridu 5000 eur. V roku 2019 na Slovensku ako v jedinej krajine Európskej únie počet predaných elektromobilov medziročne klesol, predalo sa ich len $165 \mathrm{ks}$. Tento pokles bol spôsobený práve vyčkávaním na ohlásené vládne dotácie. To spôsobilo, že rok 2020 bol považovaný rekordný rok, predalo sa $918 \mathrm{BEV}$. Ich trhový podiel bol na úrovni 1,2 \%, čo radí Slovensko k hlbokému európskemu podpriemeru.

\section{Českýtrh}

Situáciu na Českom trhu môžeme popísat' lineárnym regresným modelom, ktorý ukazuje, že so zvyšujúcim sa HDP rastú aj počty registrovaných elektromobilov. Jednoduché vyjadrenie ukazuje, že ak sa zvýši HDP o 1000 dolárov, zvýši sa počet registrovaných BEV o 28 ks. Medzi skúmanými veličinami existuje závislost' a model vyjadruje $28 \%$ variability závislej premennej ovplyvňuje nezávislá premenná. Situácia na tomto trhu je podobná situácií 
v SR. Záujem o elektromobily pomaly rastie. Celkovo bolo v ČR v roku 2020 predaných 3262 elektromobilov, pričom najvýznamnejší predaj bol zaznamenaný v mesiaci december (1159 elektromobilov). Podl'a portálu elektrickevozy.cz sa o rekord v predaji zaslúžila Škoda Auto, ktorá registrovala 741 automobilov Enyaq iV. Avšak ani jeden z Enyaqov nebol určený pre koncových zákazníkov, ale len na predvádzacie účely. [18, 19]

\section{Islandský trh}

Situáciu na trhu popisujeme lineárnym regresným modelom $\mathrm{Y}=-771,428+0,018 \mathrm{X}$, ktorý v jednoduchom vyjadrení ukazuje, že ak sa zvýši HDP o 1000 dolárov, zvýši sa počet registrovaných BEV o 18 ks. Medzi skúmanými veličinami existuje silná závislost' a model vyjadruje, že 41,6 \% variability závislej premennej ovplyvňuje nezávislá premenná. Ako už bolo spomínané, krajina je známa podporou využívania alternatívnych palív. V roku 2020 počet novo registrovaných BEV dosiahol úroveň 2457 ks, pričom v roku 2019 ich bolo 1110 .

V prvej skupine skúmaných krajín je možné na základe skúmaných štatistických charakteristík a hodnôt lineárneho regresného modelu povedat', že prijímame $\mathrm{H}_{1} \mathrm{o}$ existencii závislosti medzi hodnotou HDP a počtom novo registrovaných BEV.

Druhú skupinu skúmaných krajín tvoria Holandsko, Nórsko, Švédsko. Sú to krajiny dlhodobo považované za lídrov $\mathrm{v}$ počte prevádzkovaných $\mathrm{EV}$ a to aj $\mathrm{v}$ kategórií BEV na obyvatel'a.

\section{Holandský trh}

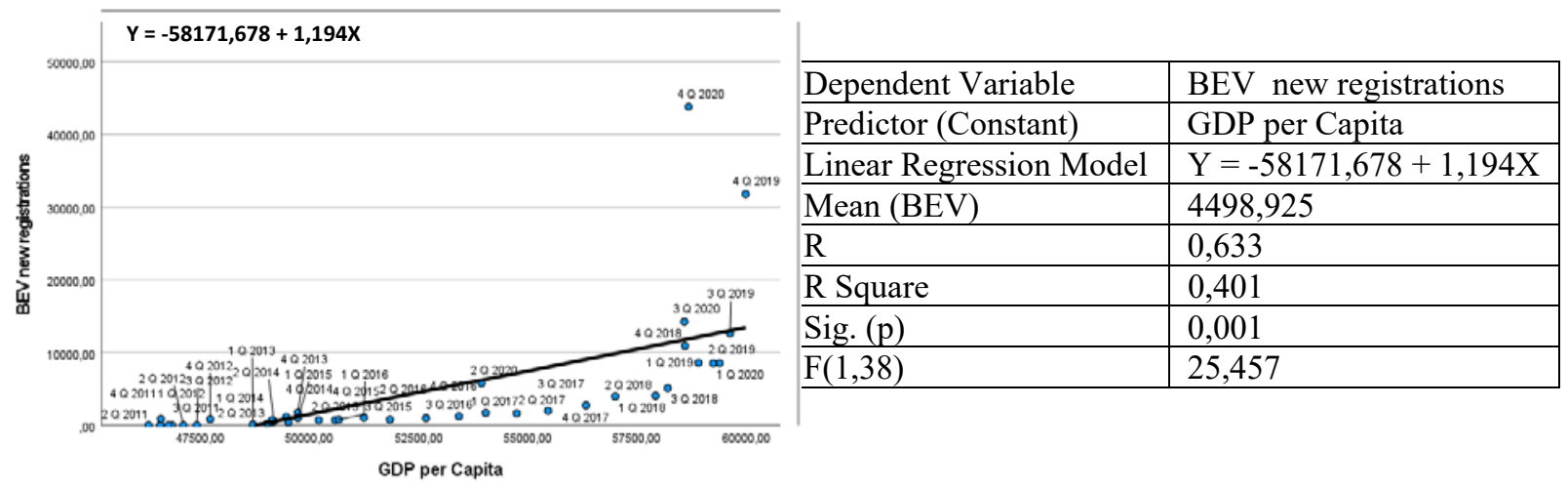

Obrázok 2 Trend vývoja elektromobility na holandskom trhu

Obrázok 2 ukazuje, že so zvyšujúcim sa HDP rastú aj počty registrovaných elektromobilov. Jednoduché vyjadrenie ukazuje, že ak sa zvýši HDP o 1000 dolárov, zvýši sa počet registrovaných BEV o 1194 ks. Medzi skúmanými veličinami existuje závislost' a model vyjadruje 40,1 \% variability závislej premennej ovplyvňuje nezávislá premenná. Z globálneho hl'adiska je možné konštatovat', že aj ked' je Holandsko považované za pomerne malý trh, z hl'adiska elektromobility je považované za trh významný. Na základe celkového počtu registrovaných hybridných vozidiel je tento trh najväčším trhom v Európe. Od roku 2015 však začal trh hybridných vozidiel pomaly klesat', čo podl'a analýz súvisí predovšetkým s obmedzením dotácií, začal však významne rást' počet registrovaných batériových elektrických vozidiel. Napríklad za december 2020 sa v Holandsku predalo viac než 30 tisíc „áut do zásuvky“, väčšinou šlo BEV čo predstavovalo 69 \% podiel na trhu. Za rok 2020 bolo v Holandsku každé štvrté nove registrované auto BEV. [19] 
Nórsky trh

Lineárnym regresným modelom $\mathrm{Y}=-45794,761+0,818 \mathrm{X}$ popisujeme situáciu na nórskom trhu. Jednoduché vyjadrenie ukazuje, že ak sa zvýši HDP o 1000 dolárov, zvýši sa počet registrovaných BEV o $818 \mathrm{ks}$. Medzi skúmanými veličinami existuje závislost' a model vyjadruje 25,3 \% variability závislej premennej ovplyvňuje nezávislá premenná. Nórsky trh je považovaný za najvýznamnejší európsky trh elektromobilov. Nórsko je krajinou, ktorá sa vyznačuje vysokou mierou podpory elektromobility. Dotácie a benefity pre používatel'ov elektromobilov sú považované celosvetovo za najštedrejšie, čo je pravdepodobne jednou z významných príčin vel'kosti tohto trhu. [19]

\section{Švédsky trh}

Situáciu na švédskom trhu možno vyjadrit’ lineárnym regresným modelom, ktorý ukazuje, že so zvyšujúcim sa HDP rastú aj počty registrovaných elektromobilov. Jednoduché vyjadrenie ukazuje, že ak sa zvýši HDP o 1000 dolárov, zvýši sa počet registrovaných BEV o 443 ks. Medzi skúmanými veličinami existuje vel'mi silná závislost' a model vyjadruje 52,5\% variability závislej premennej ovplyvňuje nezávislá premenná. V decembri 2020 bolo vo Švédsku zaregistrovaných 16929 aut s externým nabíjaním, čo predstavuje rekordný $49 \%$ podiel trhu (medziročný nárast je $215 \%$ ). Vo Švédsku na rozdiel od nórskeho a holandského trhu prevládajú plug-in hybridy (PHEV). V roku 2020 bolo na švédskom trhu viac ako polovica predaných áut elektrifikovaných. Väčšina z tohoto počtu boli plug-in hybridy (10337 ks), BEV bolo zaregistrovaných „len“ 6592, ich registrácia však vzrástla o 310 \% oproti decembru 2019, pričom plug-in hybridy „len“ o $222 \%$. [19]

V druhej skupine sledovaných krajín je možné na základe skúmaných štatistických charakteristík a hodnôt lineárneho regresného modelu povedat', že prijímame $\mathrm{H}_{1} \mathrm{o}$ existencii závislosti medzi hodnotou HDP a počtom novo registrovaných BEV.

\section{Závery}

Získané údaje o zvislosti medzi bohatstvom krajiny, vyjadreným pomocou HDP na obyvatel'a a počtom novo registrovaných BEV v jednotlivých kvartáloch je možné rozšírit' napríklad aj o posúdenie závislosti medzi hodnotami burzových indexov a počtom registrovaných BEV. Pre nedostatok priestoru uvádzame len, že aj tu sa preukázala pozitívna závislost' vo všetkých skúmaných krajinách.

Úlohou autorov je v d'alšom skúmaní hl'adat' odpovede na otázky súvisiace s rozvojom elektromobility $\mathrm{v}$ najbližšom desat'ročí a to najmä $\mathrm{v}$ súvislosti $\mathrm{s}$ ohláseným útlmom či ukončením výroby vozidiel so spal'ovacím pohonom. Tiež je zaujímavé zistit', ktoré faktory podporia alebo zabrzdia rozvoj elektromobility. Zaujímavým aspektom vo vývoji počtu registrovaných či predaných elektromobilov môže byt' aj vplyv koronakrízy, či aktuálny nedostatok polovodičových materiálov. V súvislosti $\mathrm{s}$ environmentálnym hl'adiskom nás zaujíma či elektromobilita skutočne prispeje k zníženiu množstva emisií z dopravy v SR a aký vplyv bude mat' na spotrebu elektrickej energie.

\section{Literatúra}

[1] ACEA Report 2019. Interactive map - Correlation between uptake of electric cars and GDP in the EU. [online cit.: 2021-09-22]. Available from: https://www.acea.be/statistics/article/interactive-map-correlation-between-uptake-ofelectric-cars-and-gdp-in-EU 
[2] Amsterdam Roundtables Foundation and McKinsey \& Company. 2014. Evolution Electric Vehicles in Europe: Gearing Up for a New Phase? [online cit.: 2021-10-12]. Available from: http://www.mckinsey.com/netherlands/our-insights/electric-vehicles-ineurope-gearing-up-for-a-new-phase

[3] BALL, CH.S.; VÖGELE, S.; GRAJEWSKI, M.; KUCKSHINRICHS. W. 2021 Emobility from a multi-actor point of view: Uncertainties and their impacts Technological Forecasting \& Social Change 170 (2021) DOI 10.1016/j.techfore.2021.120925

[4] BIRESSELIOGLU, M.E.; DEMIRBAG KAPLAN, M.; YILMAZ, B.K. 2018. Electric mobility in Europe: A comprehensive review of motivators and barriers in decision making processes. Transportation Research Part A: Policy and Practice, 109, pp. 1-13. DOI: 10.1016/j.tra.2018.01.017

[5] CHINORACKÝ, R.; ČOREJOVÁ, T. 2019. Impact of digital technologies on labor market and the transport sector. Transportation Research Procedia 40, pp. 994-1001

[6] CHINORACKY, R., KUROTOVA, J., JANOSKOVA, P. 2021 Measuring the impact of digital technologies on transport industry - macroeconomic perspective In: 14th International scientific conference on sustainable, modern and safe transport - ISSN 2352-1465 (online). - 1. vyd. - Amsterdam: Elsevier, s. 434-441

[7] CILIO, L.; BABACAN, O. 2021. Allocation optimisation of rapid charging stations in large urban areas to support fully electric taxi fleets. Applied Energy 295. DOI 10.1016/j.apenergy.2021.117072

[8] CUBON, P.; HRUDKAY, K. 2017. Energy optimisation of small electric urban vehicle through modification of driving cycle with implementation of the extended data. Transport Means - Proceedings of the International Conference: 806-813

[9] Electric Car Market: Get the Latest Comprehensive EV Industry Reports. [online cit.: 2021-04-12]. Available from: https://www.reportlinker.com/ci0500011/ElectricVehicle.html

[10]Electric Vehicle Charging Station Market by Level of Charging, DC fast Charging Global Forecast to 2027. [online cit.: 2021-09-12]. Available from: https://www.globenewswire.com/news-release/2021/02/10/2172870/0/en/The-globalelectric-vehicle-charging-station-market-size-is-projected-to-reach-30-758-thousandunits-by-2027-from-an-estimated-2-115-thousand-units-in-2020-at-a-CAGR-of-46-6.html

[11]Electric Vehicle Market by Component, Vehicle, Propulsion, Vehicle Drive Type, Vehicle Top Speed, Charging Point, Vehicle Class, V2G, Region-Global Forecast 2030. [online cit.: 2021-09-12]. Available from: https://www.reportlinker.com/p04664184/EVsEV-Component-EV-Infrastructure-Market-by-Govt-Regulation-Vehicle-Type-

Components-Propulsion-Recharging-Station-and-Region-Global-Forecast-to.html

[12]Electric Vehicles Market, Update 2021 - Market Size, Annual Sales, Market Share, Charging Infrastructure, and Key Country Analysis to 2030. [online cit.: 2021-09-12]. Available from: https://www.reportlinker.com/p06073088/Electric-Vehicles-MarketUpdate-Market-Size-Annual-Sales-Market-Share-Charging-Infrastructure-and-KeyCountry-Analysis-to.html

[13] GLOTZ-RICHTER, M.; KOCH, H. 2016. Electrification of Public Transport in Cities (Horizon 2020 ELIPTIC Project). Transportation Research Procedia, 14, pp. 2614-2619. DOI: $10.1016 /$ j.trpro.2016.05.416

[14]How Do All-Electric Cars Work. U.S. Department of Energy [online cit.: 2021-10-12]. Available from: https://www.afdc.energy.gov/vehicles/how-do-all-electric-cars-work

[15] https://stats.oecd.org/index.aspx?queryid=350

[16] https://www.eafo.eu/vehicles-and-fleet/m1\#

[17]https://www.eafo.eu/vehicles-and-fleet/overview 
[18]https://elektrickevozy.cz/clanky/prodeje-elektromobilu-v-cr-2020-velky-prehledpravidelne-aktualizovano

[19] https://fdrive.cz/

[20]https://www.iea.org/articles/global-ev-data-explorer

[21] https://www.nyserda.ny.gov/All-Programs/Programs/ChargeNY/Support-Electric/Mapof-EV-Registrations

[22] Inštitút environmentálnej politiky, Ministerstvo životného prostredia SR. Elektrický pohon dostáva postupne zelenú, [online cit.: 2021-05-03]. Available from:https://www.minzp.sk/iep/publikacie/komentare/elektricky-pohon-dostavapostupne-zelenu.html

[23] JANKALOVÁ, M.; KUROTOVÁ, J. 2020. Sustainability assessment using economic value added. Sustainability (Switzerland) 12 (1), 318

[24] Memorandum o budoucnosti automobilového průmyslu v ČR a Akční plán o budoucnosti automobilového průmyslu v ČR. Ministerstvo průmyslu a obchodu [online cit.: 2021-1015]. Available from: https://www.mpo.cz/cz/prumysl/zpracovatelskyprumysl/automobilovy-prumysl/memorandum-o-budoucnosti-automobiloveho-prumysluv-cr-a-akcni-plan-o-budoucnosti-automobiloveho-prumyslu-v-cr---232552/

[25]PUKALSKAS, S.; KRIAUČIŪNAS, D.; RIMKUS, A.; PRZYBYŁA, G.; DROŹDZIEL, P.; BARTA, D. 2021. Effect of hydrogen addition on the energetic and ecologic parameters of an si engine fueled by biogas. Applied Sciences (Switzerland), 2021, 11(2), pp. $1-17$

[26]RYBICKA, I.; STOPKA, O.; LUUPTÁK, V.; CHOVANCOVÁ, M.; DROŽDZIEL, P. 2018. Application of the methodology related to the emission standard to specific railway line in comparison with parallel road transport: A case study. MATEC Web of Conferences, Volume 244. DOI 10.1051/matecconf/201824403002

[27] https://www.zapsr.sk/statistiky/

\section{Grantová podpora}

Táto publikácia vznikla vd’aka podpore v rámci Operačného programu Integrovaná infraštruktúra 2014 - 2020 pre projekt: Inovatívne riešenia pohonných, energetických a bezpečnostných komponentov dopravných prostriedkov, s ITMS kódom projektu 313011V334, spolufinancovaný zo zdrojov Európskeho fondu regionálneho rozvoja

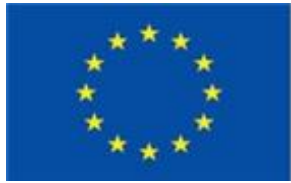

